\title{
Risk Return Analysis of Selected Stocks of Indian Financial Sector
}

\author{
Sonia Lobo ${ }^{1,2}, \&$ Ganesh Bhat S. ${ }^{3}$ \\ ${ }^{1}$ Research Scholar, College of Management \& Commerce, Srinivas University, Mangalore, \\ Karnataka, India. \\ ${ }^{2}$ Assistant Professor, Department of Humanities, NMAM Institute of Technology, Nitte, \\ Karnataka, India. \\ OrcidID: 0000-0002-8177-8855; E-mail: lobo14.sonia@gmail.com \\ ${ }^{3}$ Research Professor, College of Management \& Commerce, Srinivas University, Mangalore, \\ Karnataka, India. \\ OrcidID: 0000-0003-1950-8536; E-mail: ganbhatbvr@rediffmail.com
}

Area of the Paper: Business Management.

Type of the Paper: Research Case Study.

Type of Review: Peer Reviewed as per $|\mathrm{C}| \mathrm{O}|\mathrm{P}| \mathrm{E} \mid$ guidance.

Indexed In: OpenAIRE.

DOI: https://doi.org/10.5281/zenodo.5463885

Google Scholar Citation: $\underline{\text { IJCSBE }}$

\section{How to Cite this Paper:}

Sonia Lobo, \& Ganesh Bhat, S., (2021). Risk Return Analysis of Selected Stocks of Indian Financial Sector. International Journal of Case Studies in Business, IT, and Education (IJCSBE), 5(2), 111-124. DOI: https://doi.org/10.5281/zenodo.5463885

International Journal of Case Studies in Business, IT and Education (IJCSBE)

A Refereed International Journal of Srinivas University, India.

Crossref DOI : https://doi.org/10.47992/IJCSBE.2581.6942.0124

(C) With Authors.

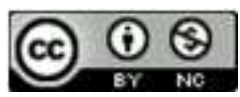

This work is licensed under a Creative Commons Attribution Non-Commercial 4.0 International License subject to proper citation to the publication source of the work.

Disclaimer: The scholarly papers as reviewed and published by the Srinivas Publications (S.P.), India are the views and opinions of their respective authors and are not the views or opinions of the S.P. The S.P. disclaims of any harm or loss caused due to the published content to any party. 


\title{
Risk Return Analysis of Selected Stocks of Indian Financial Sector
}

\author{
Sonia Lobo ${ }^{1,2}$, \& Ganesh Bhat $\mathrm{S} .^{3}$ \\ ${ }^{1}$ Research Scholar, College of Management \& Commerce, Srinivas University, Mangalore, \\ Karnataka, India. \\ ${ }^{2}$ Assistant Professor, Department of Humanities, NMAM Institute of Technology, Nitte, \\ Karnataka, India. \\ OrcidID: 0000-0002-8177-8855; E-mail: lobo14.sonia@gmail.com \\ ${ }^{3}$ Research Professor, College of Management \& Commerce, Srinivas University, Mangalore, \\ Karnataka, India. \\ OrcidID: 0000-0003-1950-8536; E-mail: ganbhatbvr@rediffmail.com
}

\begin{abstract}
Purpose: Indian stock markets are channelizing financial resources for the economic progress of the country. The Indian Financial Services sector is the subset of the stock market which is playing a key role in stock trading. The Indian Financial Services industry is multifaceted and is growing rapidly both in terms of the robust growth of existing firms and the entry of new players playing a stellar role. This surge in growth of the Financial Services sector led many investors to divert their investment towards the financial services segment. To construct an attractive portfolio, the individual investor should perform a risk-return analysis well in advance. This will assist the investor in determining the risk-return relationship in various securities. Given this background, the study is undertaken to evaluate the risk-return patterns of the Indian Financial Services sector securities.

Design/Methodology/Approach: The risk and return of sample group of companies belonging to the Indian Financial Services sector are analyzed to arrive at a monthly return by taking the monthly closing price of five financial investment companies belonging to the Standard \& Poor's BSE Finance Index for the period January 2020 to July 2021. To achieve the objectives various statistical tools such as descriptive statistics, correlation, and Beta are adopted. Also, a paired t-test is performed to check the validity of the hypothesis.
\end{abstract}

Findings: The study has brought to light that India Infoline Finance Ltd (IIFL Finance) has provided the highest monthly returns with a high beta value. Further, the tested hypothesis reveals that there exists a significant difference in the monthly returns of the S\&P BSE Finance Index and JSW Holdings.

Originality/value: The study emphasizes the risk-return analysis of selected stocks of the Indian Financial Services sector. Potential investors will benefit from this equity analysis because it will enable them to make more intelligent and accurate investment decisions.

Paper Type: A case study of the Indian Financial Services Industry

Keywords: Risk and Return, Financial Services, Investors, Beta, S\&P BSE Finance Index.

\section{INTRODUCTION :}

The Indian capital market has captivated the attention of both domestic and international investors and is recognized as one of the most dynamic markets in the world. Being an entity, it provides a platform for the various financial instruments to trade. Broadly, capital markets are classified into two types: the primary market and the secondary market. Initial Public Offerings (IPOs), Follow on Public Offerings (FPOs), Right issues, Preferential issues, and Bonds are first offered to the general public on the primary market. After duly completing the process of listing on the stock exchanges such as the Bombay Stock Exchange (BSE) and National Stock Exchange (NSE) and upon receiving the approval of the Securities and Exchange Board of India (SEBI) they are traded on the secondary market. In other words, on the 
secondary market, investors can purchase and sell securities. The primary market's progress is contingent on the secondary market's expansion.

In India, the financial services industry rose to its prominence after the economic liberalization of the 1990s. Indian financial sector consists of the institutions such as Commercial Banks, Insurance Companies, Non-banking Financial Institutions, Cooperatives, Pension Funds, Mutual Funds, and other smaller financial institutions of different shades and colors. These financial intermediaries offer a diverse range of services and these services are regarded as financial services (Goyal, 2015) [1]. The spectrum of financial services provided by financial service organizations is critical to the successful operation of any financial system. In recent times, the Indian financial services sector has emerged gigantic because of growing demand, technological innovations, regulatory backing, and growing penetration by financial firms in rural areas. The central government has brought a range of reforms to liberalize, regulate, and strengthen the financial sector's operations. The central government and the Reserve Bank of India (RBI) have taken appropriate measures to make it easier for Micro, Small, and Medium Enterprises (MSMEs) to secure funding. Though the financial services sector is growing rapidly, there are many challenges that the financial industry is facing in terms of changes in client preference, technological changes, and mainly the threats that are posted due to the globalization of financial firms (Jain, 2013) [2]. Since the financial sector's pros outweigh the cons, it appears to be more promising and appealing for investors to venture in. However, getting down to the technicalities of the business is always a good idea because it gives a better picture of how the industry is performing financially. Given the above setting, this study is undertaken wherein a detailed evaluation of risk and return of the Indian financial services stocks is ascertained.

The concept of risk and return has gained popularity, particularly in the aftermath of global economic catastrophes like the Subprime crisis of 2007 to 2010. The term 'return' refers to the profits made or losses incurred through security trading. Meanwhile, the 'risk' of an investment refers to the probability of the investor losing his/her money. There are several types of risks, but the two major forms of risks in the investment are systematic and unsystematic risks (Sharma \& Bodla, 2012) [3].

- The risk that is connected with the market return is known as systematic risk. Macroeconomic variables like inflation, interest rate changes, currency rate fluctuations, recessions, and wars are responsible for causing systematic risk. Systematic risk is beyond the control of any corporate enterprise. Systematic risk is calculated using the beta coefficient.

- Unsystematic risk is a risk that is idiosyncratic to a firm or sector. This risk is unique to a single investment or a small set of investments. Business risk, Financial Risk, Credit-Related Risk, Product Risk, Legal Risk, Liquidity Risk, Operational Issues, and so on are examples of the risks that are specific to the organization or industry. Normally, the company or industry can handle these types of unsystematic risks.

In equity investment, risk and return are highly interrelated concepts. Normally, if the return on investment is small the risk is low. On the contrary, with greater risk comes a bigger return. The stock market return also depends on the volatility of the market. Developed markets continue to give better returns with minimal volatility over extended periods and in comparison to developed countries, the Indian market has evolved to become more informational (Yadav, 2017) [4], (Patjoshi, 2016) [5]. The desired degree of return and level of risk tolerance decides the choice of an investor in selecting the various stocks. To make a smarter investment decision, performing the risk-return analysis ahead of time will prove to be beneficial for the investors. This study primarily focuses on the performance of the five financial services companies enlisted on the S\&P BSE Finance Index with an emphasis on determining the monthly rate of return of the individual stock and exposing the risk associated with each particular stock. The S\&P BSE Finance Index is taken as a benchmark for the study.

\section{LITERATURE REVIEW :}

Several researchers have significantly contributed to the area of risk and return analysis. A gist of some of the scholarly publications published in this field is discussed in this section. Prabhu, (2018) [6] analyzed the performance of Nifty stocks in the Indian capital market using the risk and return approach. The research was done to examine the risk and return of the fifty stocks that make up the Nifty 50 Index. Also, the study aims to establish the relationship of return with standard deviation and beta. The findings reveal that during the research period market return and market volatility were negatively correlated. In the article Suresh, (2018b) [7] has looked into the risk and return of private and public sector banks that 
are part of the Bank Nifty Index. In addition, each bank's performance is compared to a benchmark Index. The study suggests that private sector banks have reported the highest portfolio return. On the other hand, Karthika \& Karthikeyan, (2011) [8] attempted to find the volatility of the shares using the beta. The outcome of the research indicates that during the study period pharmaceutical, housingrelated, and automobile companies are the least risky companies for investment whereas banking, power, construction, and oil-gas companies are the riskiest sectors for investment.

Nagarajan \& Prabhakaran, (2013) [9] performed an equity evaluation on several NSE-listed FMCG firms. The share price fluctuation of FMCG companies on NSE and the risk involved in the selected companies' share price was ascertained. The findings revealed that all the companies share prices moved in a positive direction with Nifty Index. Also, Vikkraman \& Varadharajan, (2009) [10] in their article have discussed risk and return analysis of the Indian automobile sector. Systematic risk, unsystematic risk, market return, and stock return were assessed. It is noticed that during the study period based on the risk-return trade-off, Mahindra \& Mahindra company has topped the rest of the companies that were considered for the study. Bora \& Adhikary, 2015 [11] in their research have explained the association between stock returns and market returns of the selected companies under the study. It is discovered that the returns on securities and market returns have a positive association. Patjoshi \& Nandini, (2020) [12] have demonstrated the link between risk and return of Sensex and sample Steel businesses in India. The mean, kurtosis, skewness were measured. The analysis discloses that Sensex's average daily returns were positive, but all of the sample steel businesses had negative returns.

Bantwa \& Ansari, (2019) [13] evaluated the IT sector using the risk and return analysis approach. The yearly absolute return and volatility of absolute return were calculated. According to the extensive data analysis conducted, Tata Elxsi, Infibeam Avenues, and NIIT technologies have reported the highest rate of return during the study period. Balaji et al., (2018) [14] have used Statistical tools like expected returns and beta to measure the risk and return of the Automobile industry. It is found from the study that investors could choose to invest in Eicher Motors and Force Motors, as the risk is consistently low and the returns are consistently high during the study period. Joghee, (2021) [15] investigated riskreturn analysis of selected companies in the banking sector. The mean, standard deviation, covariance, variance, correlation, and beta were calculated. It is disclosed from that the study that among the seven banks taken for the study the Kotak Mahindra bank has yielded the highest return with low risk. Investing in IndusInd Bank, on the other hand, was found to have a greater risk than other banks. Suresh, (2018a) [16] in his study has examined the performance of the logistic sector taking into consideration the risk and return elements. The findings suggest that the shares of Corporate Courier and Cargo Limited have given tremendous returns whereas; the returns of Skypack service were low. Also, the beta of all the companies taken for the study was found to be very high indicating greater risk. Rao et al., (2020) [17] have made an effort to carry out a detailed analysis of the risk-return variables of the companies listed on Bank Nifty. A risk-return comparison is made between the public and private sector banks across two time periods i.e., during the UPA and NDA administrations. It is observed that during the tenure of UPA governance, all the sample stocks have given a positive rate of return. However, during the NDA governance, only 8 out of 12 stocks have rendered a positive rate of return. A.S. \& Bandi, (2021) [18] explained the volatility and return of Nifty Energy Index stocks listed on NSE. The descriptive statistics used for the calculation showcased that the stocks understudy has exhibited positive returns. Further, the application of the GARCH and ARCH model indicates that the NIFTY Energy Index stocks are highly volatile. Savsani \& Rathod, (2018) [19] discussed the risk-return analysis of the Bombay Stock Exchange in comparison to chosen Indian banking equities. Researchers have adopted paired t-test and regression techniques. It was revealed through the study that Sensex has provided high returns as compared to all other selected stocks. Also, the Sensex was positively correlated with all the bank's returns and charted high correlation with ICICI Bank returns. Further, the literature review on performing the company/industry analysis, Aithal, (2017) [20] has explained the general framework to design the industry analysis. This case study framework will help aspiring researchers develop case studies related to business management. Aithal, (2017) [21] [22] has also created an outline to perform company analysis explaining in detail the systematic procedure to be followed while drafting a business case study that will help the novice researchers.

\section{RESEARCH METHODOLOGY :}

\subsection{Objectives:}


The purpose of this piece of research is to highlight the risk-return analysis of a sample group of securities of the Indian financial services sector. The study will assist the present and prospective investors in comprehending the risk-reward trade-off of the selected financial services sector stocks within the ambit of the S\&P BSE Finance Index. The objectives of the present study are as follows:

1. To analyze the risk and return of chosen financial services companies covered by the $S \& P$ BSE Finance Index.

2. To examine the relationship between the monthly return of the S\&P BSE Finance Index and selected securities monthly return.

3. To rank, the sample companies scrips based on the return yielded.

4. To assess the beta consistency of the selected companies on the S\&P BSE Finance Index.

5. To determine the correlation coefficient of stocks with S\&P BSE Finance Index to measure the correlation.

\subsection{Statement of Hypothesis:}

While keeping the second objective in mind the following specific hypothesis is framed:

$\mathrm{H}_{0}$ : There exists no significant relationship between the return of the S\&P BSE Finance Index and the return of sample financial services companies taken for the study.

$\mathrm{H}_{1}$ : There exists a significant relationship between the return of the S\&P BSE Finance Index and the return of sample financial services companies taken for the study.

\subsection{Nature of the Study:}

The current study is empirical in nature. The monthly closing price of the Stock Market Index- S\&P BSE Finance Index and the monthly closing price of five financial services companies enlisted on the S\&P BSE Finance Index are considered for the study. Descriptive statistics are also used along with performing a t-test.

\subsection{Population of the Study:}

The sample scrips included in this study are composed of five financial investment companies listed on S\&P BSE Finance Index. The sample companies are chosen based on their market capitalization within the band of Rs. 5,000 crores to Rs 25,000 crores as of July 2021. The return and risk based on S\&P BSE Finance Index are taken as the measurement of market return and market risk respectively. The S\&P BSE Finance Index is designed to reflect the behavior and performance of the Indian financial industry and represents the major market capitalization of financial companies on BSE. Hence, is considered as a proxy for the market portfolio.

Table 1: List of Sample Group of Companies

\begin{tabular}{|l|l|l|c|}
\hline $\begin{array}{l}\text { SI. } \\
\text { No }\end{array}$ & Name of the Companies & Category & $\begin{array}{r}\text { Market Capitalization (Rs Cr) } \\
\text { As of July 2021 }\end{array}$ \\
\hline 1 & $\begin{array}{l}\text { Aditya Birla Capital Limited (AB } \\
\text { Capital) }\end{array}$ & Finance-Investment & $24,883.50$ \\
\hline 2 & $\begin{array}{l}\text { Nippon Life India Asset } \\
\text { Management Limited (Nippon) }\end{array}$ & Finance-Investment & $24,228.74$ \\
\hline 3 & $\begin{array}{l}\text { Cholamandalam Financial } \\
\text { Holdings Limited (Chola Fin } \\
\text { Hold) }\end{array}$ & Finance-Investment & $11,867.36$ \\
\hline 4 & $\begin{array}{l}\text { India Infoline Finance Ltd (IIFL } \\
\text { Finance) }\end{array}$ & Finance-Investment & $10,348.82$ \\
\hline 5 & JSW Holdings Limited & Finance-Investment & 5072.36 \\
\hline \multicolumn{2}{|l}{} \\
\hline
\end{tabular}

\subsection{Data Collection \& Period of Study:}

This piece of research is based on secondary data gathered from www.bseindia.com [24] from January 2020 to July 2021. 


\subsection{Tools Used for Data Analysis:}

Each month's closing price is used to compute the security return, which is calculated using the formula:

Where,

$$
\mathrm{I}_{\mathrm{r}}=\left(\frac{\mathrm{C}_{\mathrm{t}}-\mathrm{C}_{\mathrm{t}-1}}{\mathrm{C}_{\mathrm{t}-1}}\right)
$$

$\mathrm{I}_{\mathrm{r}}=$ Monthly rate of return of the individual company.

$\mathrm{C}_{\mathrm{t}}=$ Current month's closing price of the individual security.

$\mathrm{C}_{\mathrm{t}-1}=$ Previous month's closing price of the individual security.

The following formula is used to calculate the market's monthly rate of return:

Where,

$$
\mathrm{M}_{\mathrm{k}}=\left(\frac{\mathrm{F}_{\mathrm{t}}-\mathrm{F}_{\mathrm{t}-1}}{\mathrm{~F}_{\mathrm{t}-1}}\right)
$$

$\mathrm{M}_{\mathrm{k}}=$ Monthly Rate of return on market.

$\mathrm{F}_{\mathrm{t}}=$ Monthly closing value of S\&P BSE Finance Index for the current month.

$\mathrm{F}_{\mathrm{t}-1}=$ Monthly closing value of S\&P BSE Finance Index for the previous month.

The measure of stock volatility related to the overall market is represented by Beta, which is calculated using the following formula:

Beta $(\beta)=\left(\frac{\text { Covariance of } \mathrm{I}_{\mathrm{r}} * \text { Covariance of } \mathrm{M}_{k}}{\text { Variance of } \mathrm{M}_{\mathrm{k}}}\right)$

The correlation coefficient function is used to figure out how two variables are related linearly. The measure of the correlation coefficient is computed by using the following formula:

$$
\mathrm{r}=\frac{\mathrm{n}\left(\sum \mathrm{xy}\right)-\left(\sum \mathrm{x}\right)\left(\sum \mathrm{y}\right)}{\sqrt{\left[\mathrm{n} \sum \mathrm{x}^{2}-\left(\sum \mathrm{x}\right)^{2}\right]\left[\mathrm{n} \sum \mathrm{y}^{2}-\left(\sum \mathrm{y}\right)^{2}\right]}}
$$

A standard deviation is a statistical technique for measuring the dispersion of a dataset from its mean. The following formula is used to compute the standard deviation:

$$
\mathrm{SD}=\frac{\sqrt{ } \sum(\mathrm{x}-\overline{\mathrm{x}})}{\mathrm{n}}
$$

Skewness is defined as a measure of symmetry in distribution. The formula for skewness is as follows:

$$
\text { Skewness }=\frac{n}{(n-1)(n-2)} \sum_{i=1}^{n}\left(\frac{x_{i}-\bar{x}}{s}\right)^{3}
$$

Kurtosis reveals how far the tails of a distribution diverge from those of a normal distribution. In other words, kurtosis defines whether the distribution tails have extreme values. The formula to calculate kurtosis is as follows:

$$
\text { Kurtosis }=\frac{n(n+1)}{n(n-1)(n-2)(n-3)} \sum_{i=1}^{n}\left(\frac{x_{i}-\bar{x}}{S}\right)^{4}
$$

\subsection{Limitations of the Study:}

The following are some of the constraints of the study:

1. The research is entirely grounded on historical data obtained from the BSE and Money Control Websites. As the result, the findings of the research are fully reliant on the accuracy of the data.

2. On the subject of risk-return analysis, different specialists have differing perspectives. Therefore, the point of view adopted in this study cannot be regarded as absolute or flawless.

\section{DATA ANALYSIS \& INTERPRETATION :}

Table 2 below provides the calculated descriptive statistics of monthly returns of the sample financial services companies. 
International Journal of Case Studies in Business, IT, and Education (IJCSBE), ISSN: 2581-6942, Vol. 5, No. 2, September 2021

Table 2: Descriptive Statistics of Monthly Return of the Sample Companies

\begin{tabular}{|l|c|c|c|c|c|c|}
\hline \multicolumn{1}{|c|}{ Company Name } & $\begin{array}{c}\text { Maximum } \\
(\boldsymbol{\%})\end{array}$ & $\begin{array}{c}\text { Minimum } \\
(\boldsymbol{\%})\end{array}$ & $\begin{array}{c}\text { Mean } \\
(\boldsymbol{\%})\end{array}$ & $\begin{array}{c}\text { Standard } \\
\text { Deviation }\end{array}$ & Skewness & Kurtosis \\
\hline AB Capital & 52.9375 & -45.5484 & 3.3117 & 0.2216 & 0.3488 & 1.0383 \\
\hline Nippon & 23.2500 & -36.3800 & 1.3172 & 0.1170 & -1.7597 & 5.7417 \\
\hline Chola Fin Hold & 39.6645 & -42.9035 & 2.7418 & 0.1794 & -0.2150 & 1.5705 \\
\hline IIFL Finance Ltd & 89.2444 & -54.5371 & 7.0685 & 0.2793 & 0.9154 & 3.9487 \\
\hline JSW Holdings Limited & 41.6333 & -39.8188 & 5.8956 & 0.1709 & -0.3589 & 3.7196 \\
\hline Source: Calculated by the author
\end{tabular}

It is depicted in table 2 above that during the study period January 2020 to July 2021 the entire sample group of companies has generated positive monthly returns. It is also observed from the data that during the study period the average monthly return of IIFL Finance is high accounting for $7.0685 \%$ whereas, Nippon has produced the lowest monthly return of $1.3172 \%$. The standard deviation assesses the likelihood of risk that an investment will diverge from its average return. The lower the standard deviation of an investment, it is considered to be more stable and less volatile. The higher the standard deviation suggests more fluctuation from the average return and hence, is considered to be more volatile. The standard deviation of Nippon is the lowest (0.1170). As a result, investing in Nippon carries a lower risk than investing in all the other sample companies undertaken for the study. It is also noticed that IIFL Finance incorporates higher risk among all the companies as the standard deviation of the company has recorded the highest $(0.2793)$ during the study period. The variation in monthly return during the study period is ranging from a minimum of $-45.5484 \%$ to a maximum of $52.9375 \%$, a minimum of $36.3800 \%$ to a maximum of $23.2500 \%$, a minimum of $-42.9035 \%$ to a maximum of $39.6645 \%$, a minimum of $-54.5371 \%$ to a maximum of $89.2444 \%$, a minimum of $-39.8188 \%$ to a maximum of $41.6333 \%$ for AB Capital, Nippon, Cholamandalam, IIFL Finance, and JSW Holdings respectively. Further, it is noticed that the monthly returns of the Nippon, Cholamandalam, and JSW Holdings are negatively skewed and AB Capital and IIFL Finance are positively skewed. Positive skewness suggests that investors will experience minor losses regularly and a few large gains. Negative skewness means that investors could expect either frequent tiny wins or a few big losses. It is ascertained that during the study period investing in AB Capital and IIFL Finance will lead to experiencing recurrent small losses and few large gains. While, investing in Nippon, Cholamandalam, and JSW Holdings will result in repeated minor gains and few large losses.

In the circumstance of kurtosis, normal distributions have a kurtosis of 3 . Any value above 3 results in excess kurtosis. The kurtosis value of 0 to 3 is categorized under mesokurtic distribution. AB Capital and, Cholamandalam have a kurtosis of 1.0383 and 1.5705 respectively. Thus, they fall under mesokurtic distribution. In finance, the mesokurtic distribution trend indicates that the probability of extreme events is unlikely. Thus, the mesokurtic distribution signifies a moderate level of risk. Therefore, investing in $\mathrm{AB}$ Capital and Cholamandalam during the study period has moderate risk. Meanwhile, Nippon, IIFL Finance, and JSW Holdings have showcased a positive excessive Kurtosis (2.7417, 0.9487, and 0.7196) resulting in leptokurtic distribution. In finance, leptokurtic distribution displays that the return on investment in these types of securities yields extreme values and therefore, is considered to be very risky. However, it can also produce substantial returns to compensate for that risk. An investor who is willing to take risks can invest in these companies.

\subsection{Paired t-Test Analysis of S\&P BSE Finance Index and Aditya Birla Capital Ltd:}

Table 3 below analyzes the values of monthly returns between the S\&P BSE Finance Index and AB Capital with the support of a t-test.

Table 3: Paired t-Test of S\&P BSE Finance Index and Aditya Birla Capital Ltd

\begin{tabular}{|l|l|l|}
\hline Particulars & S\&P BSE Finance Index & AB Capital \\
\hline Mean & 0.0147 & 0.0331 \\
\hline Variance & 0.0144 & 0.0520 \\
\hline
\end{tabular}




\begin{tabular}{|l|l|l|} 
Observations & 18 & 18 \\
\hline Pearson Correlation & 0.8361 & \\
\hline Hypothesized Mean Difference & 0 & \\
\hline Df & 17 & \\
\hline t Stat & -0.5449 & \\
\hline $\mathrm{P}(\mathrm{T}<=\mathrm{t})$ one-tail & 0.2965 & \\
\hline $\mathrm{t}$ Critical one-tail & 1.7396 & \\
\hline $\mathrm{P}(\mathrm{T}<=\mathrm{t})$ two-tail & 0.5929 & \\
\hline t Critical two-tail & 2.1098 & \\
\hline Source: Calculated at 5\% level of significance & \\
\hline
\end{tabular}

The t-test result indicates that the monthly average return of the AB Capital is (0.0331) healthier than the monthly returns of the S\&P BSE Finance Index (0.0147); which denotes that the monthly return of the AB Capital has performed better than the S\&P BSE Finance Index. Meanwhile, the smaller variance of the S\&P BSE Finance Index (0.0144) compared to AB Capital (0.0520) undoubtedly agrees that in comparison to the latter, the former is more consistent. Again, the correlation values of 0.8361indicates a significant positive relationship between the S\&P BSE Finance Index and AB Capital. The p-value of 0.2965 is more than 0.05 , which points out that there is no significant difference between the monthly returns of S\&P BSE Finance and AB Capital at a level of significance of 5 percent. Subsequently, the null hypothesis $\left(\mathrm{H}_{0}\right)$ is accepted.

\subsection{Paired t-Test Analysis of S\&P BSE Finance Index and Nippon Life India Asset Management Limited:}

Table 4 reveals the outcome of the paired t-test reflecting the significance between the monthly return of the S\&P BSE Finance Index and Nippon Life India Asset Management Ltd for the study period January 2020 to July 2021.

Table 4: Paired t-Test of S\&P BSE Finance Index and Nippon Life India AML

\begin{tabular}{|l|l|l|}
\hline Particulars & S\&P BSE Finance Index & Nippon \\
\hline Mean & 0.0147 & 0.0132 \\
\hline Variance & 0.0144 & 0.0145 \\
\hline Observations & 18 & 18 \\
\hline Pearson Correlation & 0.6646 & \\
\hline Hypothesized Mean Difference & 0 & \\
\hline Df & 17 & \\
\hline t Stat & 0.0647 & \\
\hline P $(T<=t)$ one-tail & 0.4746 & \\
\hline t Critical one-tail & 1.7396 & \\
\hline P $(T<=t)$ two-tail & 0.9492 & \\
\hline t Critical two-tail & 2.1098 & \\
\hline Source: Calculated at 5\% level of significance & \\
\hline
\end{tabular}

The t-test shows that the average monthly return of the S\&P BSE Finance Index is higher (0.0147) compared to Nippon (0.0132); hence, it can be determined that the S\&P BSE Finance Index average monthly return has outperformed Nippon and offered a higher yield. It is also observed that there exists a negligible difference in the variance of both the entities (0.0144 \& 0.0145$)$ denoting the same level of consistency in returns. Further, the correlation between the S\&P BSE Finance Index and Nippon suggests that there exists a positive correlation of 0.6646 . In addition, the p-value of 0.4746 which is greater than 0.05 indicates that there is no significant difference in the monthly return of the S\&P BSE 
Finance Index and Nippon at a 5 percent level of significance. Accordingly, in this case, the null hypothesis $\left(\mathrm{H}_{0}\right)$ is accepted.

\subsection{Paired t-Test Analysis of S\&P BSE Finance Index and Cholamandalam Financial Holdings} Ltd:

Table 5 below appraisals the significance of the monthly return of the S\&P BSE Finance Index and Cholamandalam Financial Holdings Ltd. with the aid of a t-test.

Table 5: Paired t-Test of S\&P BSE Finance Index and Cholamadalam Financial Holdings Ltd.

\begin{tabular}{|l|l|l|}
\hline Particulars & S\&P BSE Finance Index & Chola Fin Hold \\
\hline Mean & 0.0147 & 0.0274 \\
\hline Variance & 0.0144 & 0.0341 \\
\hline Observations & 18 & 18 \\
\hline Pearson Correlation & 0.8807 & - \\
\hline Hypothesized Mean Difference & 0 & - \\
\hline Df & 17 & - \\
\hline t Stat & -0.5562 & - \\
\hline P(T $<=$ t) one-tail & 0.2927 & - \\
\hline t Critical one-tail & 1.7396 & - \\
\hline P(T<=t) two-tail & 0.5853 & - \\
\hline t Critical two-tail & 2.1098 & - \\
\hline Source: Calculated at 5\% level of significance \\
\hline
\end{tabular}

The findings direct that the average monthly return of Cholamandalam is more (0.0274) than that of the S\&P BSE Finance Index (0.0147) leading to the conclusion that the Cholamandalam has accomplished better monthly returns than that of S\&P BSE Finance Index. Further, the lesser variance of monthly return of the S\&P BSE Finance Index (0.0144) in comparison to Cholamandalam (0.0341) claims that the return of the S\&P BSE Finance Index is more reliable than that of Cholamandalam. Also, the correlation value of 0.8807 displays that there exists a positive correlation between the S\&P BSE Finance Index and Cholamandalam. The p-value of 0.2927 which is greater than 0.05 , displays that there is no significant difference between the monthly return of the S\&P BSE Finance Index and Cholamandalam at a level of significance of 5 percent. Consequently, the null hypothesis $\left(\mathrm{H}_{0}\right)$ is accepted.

\subsection{Paired t-Test Analysis of S\&P BSE Finance Index and India Infoline Finance Ltd:}

Table 6 below explains the relationship between the monthly returns of the S\&P BSE Finance Index and India Infoline Finance Ltd with the assistance of a t-test for the study period January 2020 to July 2021.

Table 6: Paired t-Test of S\&P BSE Finance Index and India Infoline Finance Ltd

\begin{tabular}{|l|l|l|}
\hline Particulars & S\&P BSE Finance Index & IIFL Finance \\
\hline Mean & 0.0147 & 0.0707 \\
\hline Variance & 0.0144 & 0.0826 \\
\hline Observations & 18 & 18 \\
\hline Pearson Correlation & 0.6658 & \\
\hline Hypothesized Mean Difference & 0 & \\
\hline Df & 17 & \\
\hline t Stat & -1.0517 & \\
\hline $\mathrm{P}(\mathrm{T}<=\mathrm{t})$ one-tail & 0.1538 & \\
\hline
\end{tabular}




\begin{tabular}{|l|l|l|}
$\mathrm{t}$ Critical one-tail & 1.7396 & \\
\hline $\mathrm{P}(\mathrm{T}<=\mathrm{t})$ two-tail & 0.3077 & \\
\hline $\mathrm{t}$ Critical two-tail & 2.1098 & \\
\hline \multicolumn{2}{|l|}{ Source: Calculated at 5\% level of significance } \\
\hline
\end{tabular}

It is revealed from the data that the monthly return of IIFL Finance is greater (0.0707) compared to the S\&P BSE Finance Index (0.0147) which means that IIFL Finance has earned superior returns than that of the S\&P BSE Finance Index. The variance of the monthly return of the S\&P BSE Finance Index is lower (0.0144) than IIFL Finance (0.0826) which unquestionably concurs that the S\&P BSE Finance Index is more trustworthy than IIFL Finance. It is identified from the t-test that there exists a significant positive correlation (0.6658) between S\&P BSE Finance Index and IIFL Finance's monthly returns. The $p$-value of 0.1538 which is more than 0.05 indicates that there is no significant difference between the monthly returns of the S\&P BSE Finance Index and IIFL Finance directing towards the acceptance of the null hypothesis $\left(\mathrm{H}_{0}\right)$.

4.5 Paired t-Test Analysis of S\&P BSE Finance Index and JSW Holdings Ltd:

Table 7 below shows the calculated paired t-test result of the S\&P BSE Finance Index and JSW Holdings Ltd.

Table 7: Paired t-Test of S\&P BSE Finance Index and JSW Holdings Ltd

\begin{tabular}{|l|l|l|}
\hline Particulars & S\&P BSE Finance Index & JSW Holdings Ltd \\
\hline Mean & 0.0147 & 0.0590 \\
\hline Variance & 0.0144 & 0.0309 \\
\hline Observations & 18 & 18 \\
\hline Pearson Correlation & 0.8702 & \\
\hline Hypothesized Mean Difference & 0 & \\
\hline Df & 17 & \\
\hline t Stat & -2.027 & \\
\hline $\mathrm{P}(\mathrm{T}<=\mathrm{t})$ one-tail & 0.0293 & \\
\hline t Critical one-tail & 1.7396 & \\
\hline $\mathrm{P}(\mathrm{T}<=\mathrm{t})$ two-tail & 0.0586 & \\
\hline t Critical two-tail & 2.1098 & \\
\hline Source: Calculated at 5\% level of significance & \\
\hline
\end{tabular}

It is clear from table 7 that JSW Holdings has provided higher returns $(0.0590)$ than the S\&P BSE Finance Index (0.0147). This means that JSW Holdings has performed better than the S\&P BSE Finance Index. However, the variance of the monthly return of the S\&P BSE Finance Index (0.0144) is lesser than the variance of the JSW Holdings accounting for 0.0309 indicates that the S\&P BSE Finance Index has provided more consistent returns compared to JSW Holdings. Also, the correlation value of 0.8702 reveals a significant positive correlation between both entities. Further, the p-value of 0.0293 which is less than 0.05 indicates that there is a significant difference in the monthly returns of the S\&P BSE Finance Index and monthly returns of JSW Holdings at a 5 percent level of significance. As a result, the null hypothesis is rejected $\left(\mathrm{H}_{0}\right)$.

4.6 Ranking of Sample Group of Companies Based on the Return Yielded:

As shown in Table 8 below the scrips are ranked based on the average monthly returns produced during the study period.

Table 8: Ranking of Companies Based on Monthly Returns

\begin{tabular}{|l|l|l|}
\hline Company Name & \multicolumn{1}{|c|}{$\begin{array}{c}\text { Average Monthly Return } \\
(\boldsymbol{\%})\end{array}$} & Rank \\
\hline India Infoline Finance Ltd (IIFL Finance) & 7.0685 & 1 \\
\hline JSW Holdings & 5.8956 & 2 \\
\hline
\end{tabular}




\begin{tabular}{|l|l|l|}
\hline AB Capital & 3.3117 & 3 \\
\hline Chola Fin Holdings & 2.7418 & 4 \\
\hline Nippon & 1.3172 & 5 \\
\hline Source: Calculated by the author
\end{tabular}

The top spot is grabbed by IIFL Finance with the impressive monthly average return of $7.0685 \%$ followed by JSW Holdings, AB Capital, Cholamandalam, and Nippon with the monthly return of $5.8956 \%, 3.3117 \%, 2.7418 \%$, and $1.3172 \%$ respectively.

\subsection{Estimated Beta Values of the Sample Group of Companies:}

Table 9: Beta Value of the Sample Group of Companies

\begin{tabular}{|l|l|}
\hline Company Name & Beta \\
\hline AB Capital & 1.5881 \\
\hline Nippon & 0.6664 \\
\hline Chola Fin Holdings & 1.3542 \\
\hline India Infoline Finance Ltd (IIFL Finance) & 1.5941 \\
\hline JSW Holdings Ltd & 1.2746 \\
\hline Source: Calculated by the author & \\
\hline
\end{tabular}

A stock's systematic risk is measured by its beta. When markets are bullish, high beta stocks outperform the index, and when markets are bearish, high beta stocks underperform the index. As a result, when the market prognosis is favorable, the portfolio manager will attempt to add higher beta equities, and when market trends are negative, lower beta stocks are purchased. A beta value above one indicates that the stock is more volatile than the market, whereas a beta value below one indicates that the stock is less volatile than the market. It is witnessed from Table 9 that the beta value of $\mathrm{AB}$ Capital, Cholamandalam, IIFL Finance, and JSW Holdings is above one of which IIFL Finance has showcased the highest beta value of 1.5941 . This indicates that the volatility of these stocks is high compared to the market hence, including these stocks in the portfolio makes the portfolio riskier. Whereas the beta value of Nippon is less than one (0.6664) indicating that this stock is less sensitive compared to the market and hence, adding this stock to the portfolio will make the portfolio less hazardous.

\subsection{Correlation Coefficient of S\&P BSE Finance Index and Sample Companies:}

Table 10 below elucidates the correlation between the return of the S\&P BSE Finance Index and the return of the sample group of companies.

Table 10: Correlation of S\&P BSE Finance Index and Sample Companies Monthly Returns

\begin{tabular}{|c|c|c|c|c|c|}
\hline $\begin{array}{c}\text { Index/Company } \\
\text { Name }\end{array}$ & AB Capital & Nippon & $\begin{array}{c}\text { Chola Fin } \\
\text { Holding }\end{array}$ & IIFL Finance & $\begin{array}{c}\text { JSW } \\
\text { Holdings }\end{array}$ \\
\hline S\&P BSE Finance & 0.8361 & 0.6646 & 0.8807 & 0.6658 & 0.8702 \\
\hline \multicolumn{2}{|l}{ Source: Calculated by the author }
\end{tabular}

From table 10, it is clear that the average monthly return of the S\&P BSE Finance Index is positively correlated with the monthly returns of all sample companies under study. The monthly return of the S\&P BSE Finance Index is highly correlated with the monthly return of Cholamandalam (0.8807). On the other hand, the monthly return of the S\&P BSE Finance Index has registered a lower correlation with Nippon (0.6646).

\section{FINDINGS :}

The study has revealed the following findings:

1. During the study period, January 2020 to July 2021 IIFL Finance has provided a phenomenal monthly return of $7.0685 \%$ and thus, has gained the top rank among whereas, Nippon has 
produced the least monthly return of $1.3172 \%$ and stands at fifth place among the sample group of companies taken for the study.

2. The standard deviation and beta value of the Nippon have accounted for the lowest indicating more stable returns and suggesting low risk of investment. Meantime, IIFL Finance has reported the highest standard deviation and beta value reflecting a heavy risk of investment in this company. It is evident from the analysis that when the risk is lower the returns are poorer and when the risk is higher the reward is greater.

3. Nippon, Cholamandalam, and JSW Holding's monthly returns are negatively skewed, whereas AB Capital and IIFL Finance's monthly returns are positively skewed.

4. In terms of kurtosis Nippon, IIFL Finance and JSW Holdings have resulted in producing leptokurtic distribution pointing that investing in these securities results in producing extreme values and is considered to be riskier. However, in some cases, the securities may provide excellent returns for bearing the huge risk. It is clear from the study that IIFL Finance and JSW Holdings have given better returns; whereas, Nippon has produced lower returns during the study period. The study also shows that AB Capital and Cholamandalam have generated mesokurtic distribution displaying that investment in these companies' equities comes with a moderate level of risk. It is also noted that $\mathrm{AB}$ Capital and Cholamandalam have supplied moderate returns in exchange for a moderate level of risk.

5. The t-test performed suggests that there is a significant difference between the monthly return of the S\&P BSE Finance Index and JSW Holdings. Conversely, it was found through the t-test that there exists no significant difference between the monthly returns of the S\&P BSE Finance Index and AB Capital, Nippon, Cholamandalam, and IIFL Finance.

6. The beta value of AB Capital, Cholamandalm, IIFL Finance, and JSW Holdings is greater than one; pointing out that these stocks are more volatile compared to the market, and adding them to the portfolio will cause greater risk. Further, Nippon has rendered a beta of less than one leading to the conclusion that this stock is less volatile than the market and therefore, considered to be defensive stock.

7. Finally, the outcome of the correlation coefficient calculation reveals that all the stocks were positively correlated with S\&P BSE Finance Index. The correlation coefficient of Cholamandalam recorded the highest with S\&P BSE Finance Index and the correlation coefficient of Nippon logged the least with S\&P BSE Finance Index.

\section{SUGGESTIONS :}

The following suggestions are made, keeping in mind the above findings:

1. Based on the observations it is suggested that during the study period the investor could invest in IIFL Finance as the return generated is handsome. However, the standard deviation and beta value of the stock indicate that there is a greater risk associated with investing in this stock, but it has produced the best reward in exchange for the risk. Therefore, it is a highly recommended stock for investors who are willing to take the risk.

2. JSW Holdings has also delivered impressive monthly returns. Meanwhile, AB Capital has rendered a moderate monthly return. However, the analysis shows that the risk associated with these stocks varies from medium to high. Hence, depending on the risk-bearing capacity of the investor, the stock/s can be chosen for investment.

3. During the study period, investors could prefer to invest in positively skewed securities such as $\mathrm{AB}$ Capital and IIFL Finance since; the few huge gains obtained may offset the frequent tiny losses incurred. However, the investors may also consider investing in negatively skewed securities such as Nippon, Cholamandalam, and JSW holdings if they prefer regular small gains over a few massive losses.

4. Before investing in securities, investors should conduct fundamental analysis rather than relying solely on technical analysis.

5. Respecting the universal truth, diversifying the portfolio will reduce the unsystematic risk.

\section{CONCLUSIONS :}

This study has primarily evaluated the risk and return of selected financial services companies listed on the S\&P BSE Finance Index. The statistical tools such as mean, standard deviation, skewness, kurtosis, 
beta, and correlation coefficient have been adopted to carry out the analysis. In addition, a paired t-test is performed to assess the relationship between the monthly return of the S\&P BSE Finance Index and the sample group of companies. It is found from the study that over the study period January 2020 to July 2021, IIFL Finance has displayed an excellent monthly return but it incorporates higher risk as the beta value of the stock is greater than one. Therefore, the investor who is willing to opt for the risk can invest in this company. The standard deviation and beta of Nippon were the lowest as compared to all other sample companies implying greater consistency in return and lower risk of investment. However, the return generated by Nippon is the lowest. In the circumstance of skewness, the monthly returns of AB Capital and IIFL Finance have produced positive skewness whereas; Nippon, Cholamandalam, and JSW Holding's monthly returns have displayed negative skewness. The kurtosis of monthly returns of Nippon, IIFL Finance, and JSW Holdings have generated leptokurtic distribution whereas, AB Capital and Cholamandalam have given mesokurtic distribution. The paired t-test carried out signals that there is a significant difference between the monthly return of the S\&P BSE Finance and JSW Holdings. On the other hand, it is revealed from the result of the t-test that there exists no significant difference between the monthly return of the S\&P BSE Finance Index and the monthly return of AB Capital, Nippon, Cholamandalam, and IIFL Finance. Finally, it is found that there exists a positive correlation between the S\&P BSE Finance Index monthly returns and all of the sample companies' monthly returns with Cholamandalam and Nippon reporting the highest and lowest correlation respectively with the S\&P BSE Finance Index.

\section{REFERENCES :}

[1] Goyal, P. K. (2015). An Overview of Financial Services in Indian Context. International Research Journal of Commerce Arts and Science, 6(7), 180-188.

[2] Jain, Y. (2013). Financial Services Sector at the center stage of Indian economy: Opportunities \& Challenges. Asia Pacific Journal of Management \& Entrepreneurship Research, 2(1), 209-220.

[3] Sharma, G. D., \& Bodla, B. S. (2012). Rewards \& Risks in Stock Markets: A Case of South Asia. The International Journal of Applied Economics \& Finance, 6(2), 37-52.

[4] Yadav, S. (2017). Stock Market Volatility-A Study of Indian Stock market. Global Journal for Research Analysis, 6(4), 629-632.

[5] Patjoshi, P. K. (2016). Comparative risk return analysis of Bombay stock market with selected banking stocks in India. International Journal of Management \& Social Sciences, 4(1), 2016.

[6] Prabhu, R. N. (2018). Risk \& return analysis of nifty stock in Indian capital market. International Journal of Multidisciplinary Research and Development, 5(3), 8-12.

[7] Suresh, A. S. (2018b). Study on Comparison of Risk-Return Analysis of Public and Private Sector Banks listed on Bank Nifty. Economic Research, 2(1), 1-8.

[8] Karthika, D. P., \& Karthikeyan, P. (2011). A Study on Comparative Analysis of Risk and Return with reference to Selected stocks of BSE Sensex Index, India. The International Journal's Research Journal of Social Science and Research, 1(04), 101-114.

[9] Nagarajan, S., \& Prabhakaran, K. (2013). A Study on Equity Analysis of Selected FMCG Companies Listed on NSE. International Journal of Management Focus, 1(1), 1-7.

[10] Vikkraman, P., \& Varadharajan, P. (2009). A Study on Risk \& Return analysis of Automobile industry in India (2004-2007). Journal of Contemporary Research in Management, 1(1), 35-40.

[11] Bora, B., \& Adhikary, A. (2015). Risk and Return Relationship-An Empirical Study of BSE Sensex Companies in India. Universal Journal of Accounting and Finance, 3(2), 45-51.

[12] Patjoshi, P. K., \& Nandini, G. (2020). Comparative Risk and Return Analysis of Bombay Stock Exchanges and Steel Sector in India. Gedrag \& Organisatie Review, 33(2), 795-802.

[13] Bantwa, A., \& Ansari, F. U. (2019). Risk Return Analysis of Equity Stocks: A Study of Selected Indian IT Companies. MUDRA: Journal of Finance and Accounting, 6(1), 31-43. https://doi.org/10.17492/mudra.v6i1.182822 
[14] Balaji, C., Kusuma, G. D. V., \& Kumar, B. R. (2018). Risk and Return Analysis of Equity Shares of Selected Companies in Automobile Industry. Asian Journal of Multi-Disciplinary Research, 4(2), 37-42. http://dx.doi.org/10.20468/ajmdr.2018.02.09.

[15] Joghee, M. V. (2021). A Study on Risk and Return Analysis of Selected Banking Securities. Turkish Journal of Computer and Mathematics Education (TURCOMAT), 12(11), 122-127.

[16] Suresh, A. S. (2018a). Equity analysis of selected Logistics sectors stocks. Asian Journal of Management, 9(4), 1301-1304

[17] Rao, D., Srinivasa, M., Podile, D., \& Navvula, D. (2020). Risk and Return Analysis of Selected Nifty Banking Stocks. European Journal of Molecular \& Clinical Medicine, 7(4), 1010-1018.

[18] Suresh, A. S., \& Bandi, S. (2021), Volatility Modelling for Nifty Energy Index Stocks Listed in NSE. International Journal of Advance Research in Management and Social Science, 10(2), 1-10.

[19] Savsani, M., \& Rathod, U. (2018). Comparative Risk Return Analysis of Bombay Stock Market with Selected Banking Stocks in India. International Journal of Scientific Research in Science and Technology, 4(5), 908-916.

[20] Aithal, P. S. (2017). Industry Analysis-The First Step in Business Management Scholarly Research. International Journal of Case Studies in Business, IT and Education (IJCSBE), 1(1), 113.

[21] Aithal P. S. (2017). An effective method of developing business case studies based on company analysis. International Journal of Engineering Research and Modern Education (IJERME), 2(1), $16-27$.

[22] Aithal, P. S. (2017). Company Analysis-The Beginning Step for Scholarly Research. International Journal of Case Studies in Business, IT and Education (IJCSBE), 1(1), 1-18.

[23] www.moneycontrol.com/stocks/market info/marketcap/bse/finance-investment.html?classic=true last accessed on 28.07.2021

[24] www.bseindia.com retrieved on 30.07.2021 